\title{
REVIEW
}

\section{PERSPECTIVES OF ADULT SURVIVORS OF COLORECTAL CANCER WITH AN OSTOMY ON THEIR NEEDS: SYNTHESIS OF QUALITATIVE RESEARCH STUDIES}

\author{
Yulius Tiranda ${ }^{1}$, Pulsuk Siripul ${ }^{2}$, Bumpenchit Sangchart ${ }^{3}$, Cahyu Septiwi $^{4}$ \\ ${ }^{1}$ Department of Adult Nursing, Nursing Study Program, STIKes Muhammadiyah Palembang, South Sumatera, Indonesia \\ ${ }^{2}$ Department of Pediatrics, Faculty of Nursing, Khon Kaen University, Khon Kaen, Thailand \\ ${ }^{3}$ Department of Adult Nursing, Faculty of Nursing, Khon Kaen University, Khon Kaen, Thailand \\ ${ }^{4}$ Department of Adult Nursing, Nursing Study Program, STIKes Muhammadiyah Gombong, Central Java, Indonesia
}

Received June 18, 2019; Accepted October 24, 2019. Copyright: This is an open access article distributed under the terms of the Creative Commons Attribution International License (CC BY). http://creativecommons.org/licenses/by/4.0/

\begin{abstract}
Aim: Colorectal cancer survivors must address the challenges of living with their condition, while their primary needs change over time. The extent to which the needs of survivors are fulfilled is one of the key indicators of success throughout the illness. This study aimed to explore and expand understanding of the needs of adult survivors of CRC with ostomy, according to their own views and experiences. Design: A synthesis of qualitative research studies. Methods: Four electronic databases were used: Scopus, Cumulative Index to Nursing and Allied Health Literature (CINAHL), Proquest, and Science Direct, published 20002016, and using PRISMA guidelines as search strategies. The Critical Appraisal Skills Programme qualitative research checklist was used to ensure the quality of the articles. A three-point system was used to estimate the average score for all articles. Results: Initial codes were employed by coding the primary study line-by-line. The codes were then structured into eight descriptive themes, and, finally, three new analytical themes were established, including information needs, experiences of having stoma, and surviving for a better life. Conclusion: Information related to the illness is pivotal for CRC survivors in dealing with their current and future conditions. In addition, support from those closest to them, family, and healthcare workers has a positive impact on the acceptance of the illness and the will to survive. Determining the subjective needs of adult CRC survivors with ostomies is crucial if they are to be helped to adapt successfully to conditions and to continue living normal lives.
\end{abstract}

Keywords: adult survivors, colorectal cancer, needs, qualitative synthesis, thematic synthesis.

\section{Introduction}

Colorectal cancer (CRC) is one of the most commonly diagnosed cancers worldwide (Ferlay et al., 2013; Stewart, Wild, 2014; Siegel, Miller, Jemal, 2015). It has the third highest incidence of all types of cancer (Center et al., 2009; Ferlay et al., 2013). Around a tenth of all cancer incidence (Haggar, Boushey, 2009) for both men and women is usually detected in the age group > 50 years. CRC-related mortality rates in developed countries have been declining steadily over the past 20 years (Torre et al., 2015), and in the US, the relative survival rate at five years is currently around 64\% (Sun et al., 2013). In contrast, $\mathrm{CRC}$ cases have been rising rapidly in developing countries and westernized Asian countries (Sung et al., 2005; Arnold et al., 2017), now accounting for almost $45 \%$ of the total number of cases (Favoriti et al., 2016).

The increasing number of CRC cases has affected the expanding needs of CRC survivors. The term "cancer

Corresponding author: Yulius Tiranda, Department of Adult Nursing, Nursing Study Program, STIKes Muhammadiyah Palembang, Jl. A. Yani 13 Ulu, Plaju, Palembang, South Sumatera, Indonesia; email: yuliustiranda@ stikesmp.ac.id survivors" refers to a broad range of patients, starting from those who have recently ended their active treatment cycle to patients who have had follow-up checks for years, and which will continue throughout their lives (Hoekstra, Heins, Korevaar, 2014). There are three distinct phases for CRC survivors: diagnosis of the illness, the first treatment, and the changeover from receiving treatment to being classed as extended survivors and long-term survivors (more than five years) (Chow, Ting, Su, 2014). CRC survivors will face the possibility of secondary cancers, side effects of the treatment, and comorbid condition (Denlinger, Engstrom, 2011). Commonly, CRC survivors only have basic information about their illness, in other words, they do not have a deep understanding of their condition (Salz et al., 2014), which presents an obstacle. Long-term follow-up, health support, and lifestyle modifications remain essential components of care of CRC survivors (Denlinger, Barsevick, 2009), with every patient having their own priority of needs.

A number of studies have reported the various challenges facing CRC survivors, including physical, psychological, sexual, and spiritual problems that can 
be complex and persistent, resulting from both the illness and the treatments (Mahjoubi et al., 2012; Kimura et al., 2014; Kimura et al., 2016). CRC survivors need to directly assess and identify their specific needs, as well as the perceived magnitude of them. In this current study, needs are understood as daily activities which have benefits in aiding survivors to achieve a normal life. It is important that nurses and healthcare providers are fully informed regarding the needs of cancer survivors in order to help them lead as normal a life as possible. Virginia Henderson's Nursing Need Theory emphasizes the role of nursing that supports individual independence whenever possible. Unfortunately, most qualitative syntheses discuss models of survivorship, the psychological, physical, and social problems faced by the survivors, and the supportive care needs of CRC survivors. Only a limited number of syntheses of qualitative research studies focus on the needs of adult CRC survivors with ostomies. While there are a growing number of studies of CRC survivors, a patient with an ostomy might face challenges if they have not been able to adapt successfully. Understanding the primary needs of CRC survivors can help them to survive and adapt successfully to their condition and situation. A synthesis of qualitative research studies aims to give a broader, deeper, and more comprehensive understanding, revealing details of particular phenomena - in this case, the needs of CRC survivors - which could provide valuable information. The aim of this current study is to explore the subjective needs of CRC survivors using a synthesis of qualitative research studies.

\section{Aim}

The aim of this current study was to explore the subjective needs of CRC survivors using a synthesis of qualitative research studies.

\section{Methods}

\section{Design}

A synthesis of qualitative research studies was chosen for this review since this approach can expose the broader dimensions of healthcare by exploring the phenomena through primary qualitative research (Ring, Jepson, Ritchie, 2011). The purpose of a synthesis of qualitative research studies is to show that the results of research can be more effective, efficient and applicable in the field by integrating inter-related qualitative research (Edwards, Kaimal, 2016). The thematic synthesis by Thomas and Harden (2008) was used in the study, beginning with line-byline coding of the primary studies, followed by construction of descriptive themes, and, finally, the development of analytical themes.

\section{Eligibility criteria}

The inclusion criteria for articles were: 1) primary studies; 2) studies covering the population with colorectal cancer (defined as individuals aged 18 years or over when diagnosed); 3) and those having undergone surgery and colostomy or ileostomy. Conversely, articles on surgical technique, or the treatment process (chemotherapy or radiotherapy), articles without a specific focus on colorectal cancer, and thesis studies were excluded, especially those measuring instrument validity, case studies, editorials, and commentaries. The current study was limited to English language, full text, peer-reviewed journals to guarantee quality.

\section{Search Strategy}

The search strategies systematically used the PRISMA guideline to assess the needs of CRC survivors (Moher et al., 2009). Searches were conducted manually in order to locate articles that matched the inclusion criteria for relevant articles. In this study, the reviewers used four electronic databases: Scopus, the Cumulative Index to Nursing and Allied Health Literature (CINAHL), Proquest, and Science Direct, from 2000 to 2016, providing a good number of relevant papers. Search terms or keywords were divided into three concepts: needs, or difficulties, or barriers, or care needs, or healthcare needs, or demands, or challenges, or unmet needs, or met needs; AND colorectal cancer, or colon cancer, or rectal cancer, or bowel cancer, or survivors, or survival, or survivorship; AND ostomy, or ostomies, or ostomates, or colostomy, or ileostomy, or stoma.

\section{Study Selection}

The first step in the selection process was to identify articles in the four databases using specific search terms or keywords. The reviewers independently screened all records using the inclusion and exclusion criteria, after removing duplicates, titles, and abstracts. Three additional records were excluded due to duplication. A total of 1,359 articles were screened by titles and abstracts by the two reviewers (YT, CS), who worked independently by reading the details of titles and abstracts. The next selection was based on the following criteria: full articles, peer-reviewed, between 2000 and 2016, English language, academic journals, colostomy and ileostomy. In this step, 1,281 articles were excluded for failing to match the inclusion criteria: general cancer, medical treatment, a different stoma, therapy, specific sample of pregnant women, chemotherapy and radiotherapy, diagnostic: 
MRI/CT scan, surgery techniques, instrument and psychometric validation, and nurse roles. The next stage was the screening of the full papers of 78 articles, 59 of which were excluded for being ineligible for this study: quantitative research and mixed method research, not primary research, review, protocol, and conference proceedings. The authors screened all the articles before reaching consensus on the selected articles. Finally, 19 articles were deemed eligible for use in this study (Figure 1).

\section{Evaluation of quality articles}

To measure the quality of the articles, the two authors (YT, CS) used the Critical Appraisal Skills Programme (CASP) qualitative research checklist, consisting of ten questions and eight subcategories: research design, recruitment, data collection, researcher-participant relationship, ethical issues, data analysis, findings, and the value of the research
(Critical Appraisal Skills Programme, 2016). The aim of the first two questions is to screen the suitability of articles to being subjected to rigorous study. A threepoint system was used in this study to estimate the average score for all articles relating to the eight subcategories ( $1=$ weak; $2=$ moderate; $3=$ strong $)$ (Coffey et al., 2016). The scores for this paper ranged between 8 to 24, while overall scores were calculated from the sum of each paper. When there were differences of opinion between the two reviewers (YT, CS), a third reviewer (PS or BS) was consulted to reach an agreement. This quality review was conducted to aid readers' critical acceptance of the credibility of the included papers' findings, and thus papers were not excluded for their scores. The final result of the full-stage review was decided by consensus among all the authors (YT, PS, BS, and CS).

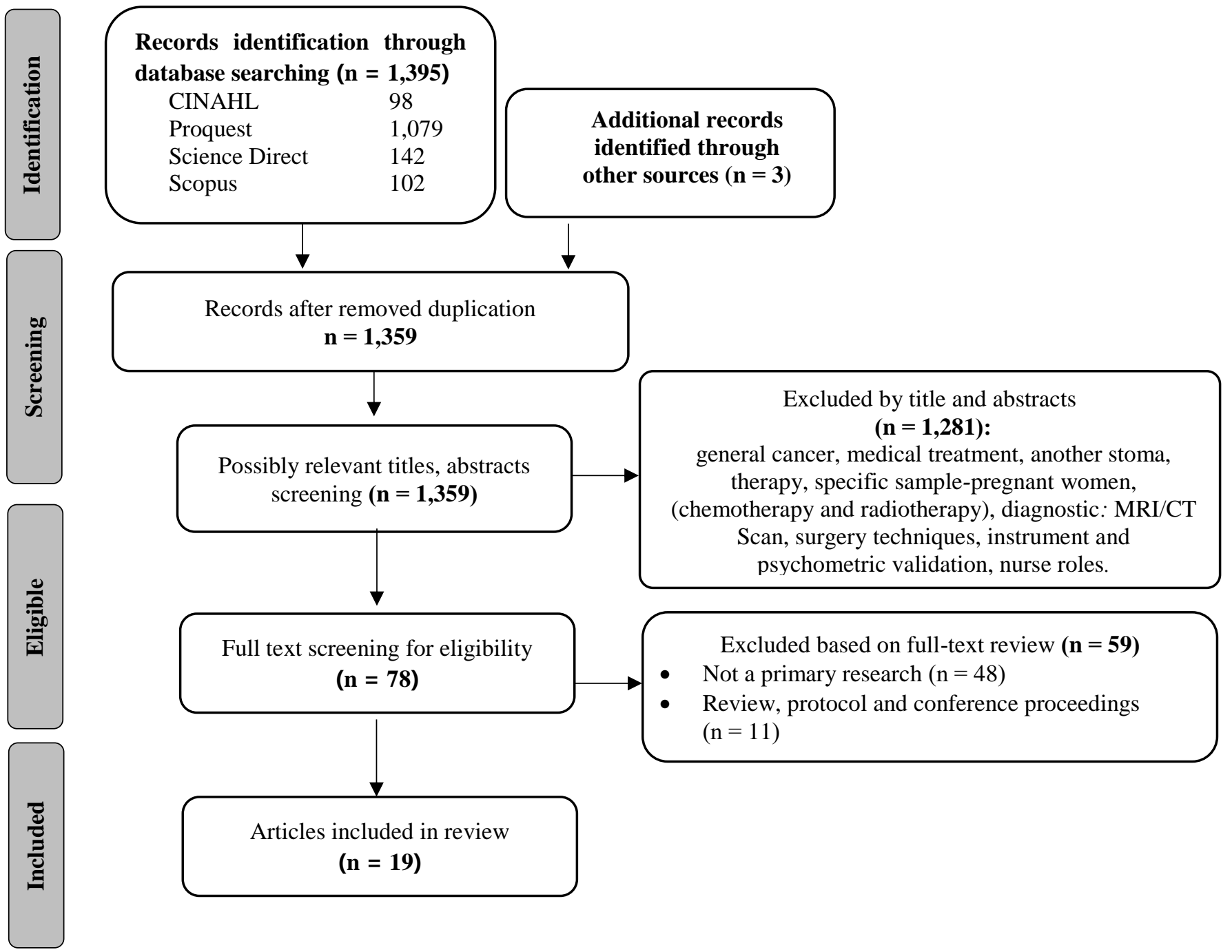

Figure 1 Flow diagram of article study selection 


\section{Data Extraction}

Currently, there is no single agreement on classification of different types of qualitative syntheses, and different authors adopt varying frameworks (Campbell et al., 2011). The authors extracted data independently from all the included studies, and discrepancies were resolved through discussion (Table 1). The data synthesis of thematic synthesis was performed in three phases as developed by Thomas and Harden (2008). The first stage, quotations from the primary studies, involved the researchers (YT, CS) reading and coding line-by-line to produce the initial codes. The two researchers read and re-read the articles, with reference to earlier published articles, and then created a table of quotations to produce the initial codes. Next, they searched the codes for pre-existing meanings, and new concepts were created when deemed necessary from the initial codes at the earlier stages. In the second stage, the codes were structured into descriptive themes to describe the developing themes from the previous stages. Lastly, the descriptive themes were developed into analytical themes. This process resulted in three analytical themes, all of which were confirmed by PS, BS.

Table 1 Overview of characteristics of the included studies (Part 1)

\begin{tabular}{|c|c|c|c|c|c|}
\hline Author (year) & Aim (objectives) & Method & Participants & $\begin{array}{l}\text { Data } \\
\text { collection }\end{array}$ & $\begin{array}{l}\text { Data } \\
\text { analysis }\end{array}$ \\
\hline $\begin{array}{l}\text { Andersson, } \\
\text { Engström, } \\
\text { Söderberg } \\
(2010)\end{array}$ & $\begin{array}{l}\text { to describe the experience of } \\
\text { women living with a colostomy as a } \\
\text { result of rectal cancer }\end{array}$ & qualitative study & 5 women & interviews & $\begin{array}{l}\text { thematic } \\
\text { content } \\
\text { analysis }\end{array}$ \\
\hline $\begin{array}{l}\text { Hall et al. } \\
(2012)\end{array}$ & $\begin{array}{l}\text { to explore the experiences and } \\
\text { support needs of people with } \\
\text { colorectal cancer }\end{array}$ & qualitative study & $\begin{array}{l}30(17 \text { men; } 13 \\
\text { women }) \text {, aged } \\
37-85 \text { years }\end{array}$ & $\begin{array}{l}\text { semi- } \\
\text { structured } \\
\text { interview }\end{array}$ & $\begin{array}{l}\text { analytical } \\
\text { method }\end{array}$ \\
\hline $\begin{array}{l}\text { Sahay, Gray, } \\
\text { Fitch (2000) }\end{array}$ & $\begin{array}{l}\text { to learn about the experiences of } \\
\text { persons with colorectal cancer, } \\
\text { about their perceptions of their } \\
\text { illness, and the meaning they } \\
\text { attribute to their situation }\end{array}$ & $\begin{array}{l}\text { qualitative } \\
\text { descriptive study }\end{array}$ & $\begin{array}{l}20, \text { aged } 48-87 \\
\text { years }\end{array}$ & $\begin{array}{l}\text { interviewed } \\
\text { over the } \\
\text { telephone }\end{array}$ & $\begin{array}{l}\text { coding } \\
\text { categories }\end{array}$ \\
\hline $\begin{array}{l}\text { Beaver et al. } \\
(2010)\end{array}$ & $\begin{array}{l}\text { to explore patient perceptions of } \\
\text { their experiences of follow-up care } \\
\text { after treatment for colorectal cancer }\end{array}$ & $\begin{array}{l}\text { exploratory } \\
\text { qualitative study }\end{array}$ & $\begin{array}{l}27(14 \text { men; } 13 \\
\text { women), aged } \\
59-86 \text { years }\end{array}$ & interviews & $\begin{array}{l}\text { thematic } \\
\text { analysis }\end{array}$ \\
\hline $\begin{array}{l}\text { Landers, } \\
\text { McCarthy, } \\
\text { Savage (2012) }\end{array}$ & $\begin{array}{l}\text { to explore the bowel symptom } \\
\text { experiences and symptom } \\
\text { management strategies following } \\
\text { sphincter saving surgery for rectal } \\
\text { cancer }\end{array}$ & qualitative analysis & 123 & $\begin{array}{l}\text { semi- } \\
\text { structured } \\
\text { interview }\end{array}$ & $\begin{array}{l}\text { deductive } \\
\text { content } \\
\text { analysis }\end{array}$ \\
\hline $\begin{array}{l}\text { Sun et al. } \\
(2014)\end{array}$ & $\begin{array}{l}\text { to describes the health-care-related } \\
\text { experiences of long-term CRC } \\
\text { survivors with ostomies who } \\
\text { participated in a community-based } \\
\text { study with focus groups }\end{array}$ & qualitative study & $\begin{array}{l}33(17 \text { men; } 16 \\
\text { women }) \text {, aged } \\
63-76 \text { years }\end{array}$ & $\begin{array}{l}\text { focus group } \\
\text { discussion }\end{array}$ & $\begin{array}{l}\text { thematic } \\
\text { analysis }\end{array}$ \\
\hline $\begin{array}{l}\text { Grant et al. } \\
(2011)\end{array}$ & $\begin{array}{l}\text { to describe how gender shapes the } \\
\text { concerns and adaptations of long- } \\
\text { term (i.e., more than five years) } \\
\text { CRC survivors with ostomies }\end{array}$ & qualitative study & $\begin{array}{l}33 \text { (17 men; } 16 \\
\text { women) }\end{array}$ & $\begin{array}{l}\text { focus group } \\
\text { discussion }\end{array}$ & $\begin{array}{l}\text { content } \\
\text { analysis }\end{array}$ \\
\hline $\begin{array}{l}\text { Brown, } \\
\text { Greenfield, } \\
\text { Thompson } \\
(2016)\end{array}$ & $\begin{array}{l}\text { to describe patient knowledge and } \\
\text { awareness of long-term and late } \\
\text { onset treatment consequences } \\
\text { amongst CRC survivors }\end{array}$ & qualitative study & $\begin{array}{l}19(11 \text { men; } 8 \\
\text { women }) \text {, aged } \\
37-84 \text { years }\end{array}$ & $\begin{array}{l}\text { semi- } \\
\text { structured } \\
\text { interviews }\end{array}$ & $\begin{array}{l}\text { framework } \\
\text { analysis }\end{array}$ \\
\hline $\begin{array}{l}\text { Danielsen et al. } \\
\text { (2013) }\end{array}$ & $\begin{array}{l}\text { to explore the impact of a } \\
\text { permanent intestinal ostomy on } \\
\text { everyday life, and to gain further } \\
\text { knowledge of patients' educational } \\
\text { needs }\end{array}$ & $\begin{array}{l}\text { phenomeno-logical } \\
\text { and hermeneutic } \\
\text { technique }\end{array}$ & 15 & $\begin{array}{l}\text { focus group } \\
\text { interviews }\end{array}$ & $\begin{array}{l}\text { content } \\
\text { analysis }\end{array}$ \\
\hline
\end{tabular}


Table 1 Overview of characteristics of the included studies (Part 2)

\begin{tabular}{|c|c|c|c|c|c|}
\hline Author (year) & Aim (objectives) & Method & Participants & $\begin{array}{l}\text { Data } \\
\text { collection }\end{array}$ & $\begin{array}{l}\text { Data } \\
\text { analysis }\end{array}$ \\
\hline $\begin{array}{l}\text { Anderson, } \\
\text { Steele, Coyle } \\
(2013)\end{array}$ & $\begin{array}{l}\text { to explore patient needs for advice on } \\
\text { diet, activity and lifestyle; patient } \\
\text { beliefs about the role of diet, activity } \\
\text { and lifestyle for reducing disease risk; } \\
\text { and preferred formats, timings and } \\
\text { routes of delivery for such guidance }\end{array}$ & qualitative study & $\begin{array}{l}40 \text { (6 groups; } 20 \\
\text { men; } 20 \text { women }) \\
\text { aged } 27-84 \text { years }\end{array}$ & $\begin{array}{l}\text { focus group } \\
\text { discussion } \\
\text { (face-to- } \\
\text { face } \\
\text { interview) }\end{array}$ & $\begin{array}{l}\text { framework } \\
\text { analysis }\end{array}$ \\
\hline Taylor (2001) & $\begin{array}{l}\text { to increase understanding of the } \\
\text { experiences of a sample of colorectal } \\
\text { cancer patients }\end{array}$ & $\begin{array}{l}\text { hermeneutical } \\
\text { phenomenological } \\
\text { study }\end{array}$ & 8 & $\begin{array}{l}\text { semi- } \\
\text { structured, } \\
\text { in-depth, } \\
\text { face- to- } \\
\text { face } \\
\text { interviews }\end{array}$ & $\begin{array}{l}\text { thematic } \\
\text { Analysis }\end{array}$ \\
\hline $\begin{array}{l}\text { Appleton et al. } \\
(2013)\end{array}$ & $\begin{array}{l}\text { to explore in-depth, the lived } \\
\text { experience of survivors of colorectal } \\
\text { cancer }\end{array}$ & $\begin{array}{l}\text { cross sectional } \\
\text { qualitative study }\end{array}$ & $\begin{array}{l}13(8 \text { men; } 5 \\
\text { women }) \text { aged } \\
45-84 \text { years }\end{array}$ & $\begin{array}{l}\text { semi- } \\
\text { structured, } \\
\text { face-to-face } \\
\text { interviews }\end{array}$ & $\begin{array}{l}\text { interpretative } \\
\text { phenomeno- } \\
\text { logical } \\
\text { analysis }\end{array}$ \\
\hline $\begin{array}{l}\text { Taylor, } \\
\text { Richardson, } \\
\text { Cowley (2010) }\end{array}$ & $\begin{array}{l}\text { to understand how individuals } \\
\text { recover following colorectal cancer } \\
\text { surgery }\end{array}$ & grounded theory & 16 & $\begin{array}{l}\text { in-depth } \\
\text { interviews } \\
\text { (face-to- } \\
\text { face } \\
\text { interviews } \\
\text { and } \\
\text { telephone } \\
\text { interviews) }\end{array}$ & $\begin{array}{l}\text { constant } \\
\text { comparative } \\
\text { analysis }\end{array}$ \\
\hline $\begin{array}{l}\text { Taylor, } \\
\text { Rischardson, } \\
\text { Cowley (2011) }\end{array}$ & $\begin{array}{l}\text { to examine the difficulties } \\
\text { experienced during different phases } \\
\text { of recovery from surgery over time }\end{array}$ & grounded theory & 16 & $\begin{array}{l}\text { semi- } \\
\text { structured } \\
\text { interviews }\end{array}$ & $\begin{array}{l}\text { constant } \\
\text { comparative } \\
\text { analysis }\end{array}$ \\
\hline $\begin{array}{l}\text { Sun et al. } \\
(2013)\end{array}$ & $\begin{array}{l}\text { describes persistent ostomy-specific } \\
\text { concerns and adaptations of long- } \\
\text { term ( } 5 \text { years) CRC survivors }\end{array}$ & qualitative study & $\begin{array}{l}33 \text { (17 men; } 16 \\
\text { women) }\end{array}$ & $\begin{array}{l}\text { focus } \\
\text { groups } \\
\text { discussion }\end{array}$ & $\begin{array}{l}\text { thematic } \\
\text { analysis }\end{array}$ \\
\hline $\begin{array}{l}\text { Palmer et al. } \\
(2013)\end{array}$ & $\begin{array}{l}\text { to identify and describe the health } \\
\text { goals of CRC survivors who have } \\
\text { completed cancer treatment }\end{array}$ & qualitative study & 41 & $\begin{array}{l}\text { semi- } \\
\text { structured } \\
\text { qualitative } \\
\text { interviews }\end{array}$ & $\begin{array}{l}\text { content } \\
\text { analysis }\end{array}$ \\
\hline $\begin{array}{l}\text { Broughton, } \\
\text { Bailey, Linney } \\
(2004)\end{array}$ & $\begin{array}{l}\text { to investigate the care of large bowel } \\
\text { cancer from patients' and } \\
\text { carers'perspectives }\end{array}$ & qualitative study & $\begin{array}{l}49 \text { (aged 37-92 } \\
\text { years) }\end{array}$ & $\begin{array}{l}\text { semi- } \\
\text { structured } \\
\text { interviews }\end{array}$ & $\begin{array}{l}\text { framework } \\
\text { analysis }\end{array}$ \\
\hline $\begin{array}{l}\text { Sjövall et al. } \\
(2011)\end{array}$ & $\begin{array}{l}\text { to investigate how life situation of } \\
\text { persons with advanced colorectal } \\
\text { cancer and their partners is affected } \\
\text { by living with the disease and its } \\
\text { treatment }\end{array}$ & $\begin{array}{l}\text { descriptive } \\
\text { qualitative study }\end{array}$ & $\begin{array}{l}21 \text { (12 survivors; } \\
9 \text { partners) }\end{array}$ & interviews & $\begin{array}{l}\text { content } \\
\text { analysis }\end{array}$ \\
\hline $\begin{array}{l}\text { McMullen et } \\
\text { al. (2011) }\end{array}$ & $\begin{array}{l}\text { family caregiving; explores how } \\
\text { long-term CRC survivors manage } \\
\text { their ostomy care }\end{array}$ & ethnography & $\begin{array}{l}31 \text { (15 received } \\
\text { no help with } \\
\text { ostomy care; } 11 \\
\text { received help } \\
\text { with ostomy care } \\
\text { and other } \\
\text { activities; } 5 \\
\text { received only } \\
\text { ostomy care } \\
\text { assistance, with } \\
\text { no other form of } \\
\text { informal or paid } \\
\text { caregiving }\end{array}$ & $\begin{array}{l}\text { interviews, } \\
\text { field notes }\end{array}$ & $\begin{array}{l}\text { thematic } \\
\text { analysis }\end{array}$ \\
\hline
\end{tabular}




\section{Results}

Synthesis of the eligible articles resulted (Table 2) in three analytical themes were: 1) information needs (information regarding everyday life, and choosing the right foods); 2) experiences of having stoma (challenge of having stoma, stoma complications, and coping process); and 3) surviving towards a better life (moving forwards, support networks, and opportunities for discussion).

\section{Information needs}

\section{Information regarding daily activities}

For CRC survivors, detailed and comprehensive information about the illness is fundamental to dealing with and living with the impact of the illness. Initial information in comprehensible language is needed by the survivors to help them know more about their situation (Sahay, Gray, Fitch, 2000; Sun et al., 2014), including complications that might occur in the future
(Andersson, Engström, Söderberg, 2010; Beaver et al., 2010; Hall et al., 2012). Another issue is informing the patients about how the illness could affect their sexual life, particularly for survivors of productive ages (Hall et al., 2012). Male CRC survivors usually suffer from erectile dysfunction (Brown, Greenfield, Thompson, 2016), which could influence their sexual activity (Grant et al., 2011). Furthermore, interaction with the community also plays a pivotal role for CRC survivors in increasing their confidence and acceptance of their condition. When going out into the community, they choose the most convenient and comfortable clothes to wear (Andersson, Engström, Söderberg, 2010; Beaver et al., 2010). Female survivors have more issues than male survivors due to limited opportunities to wear jeans or anything close-fitting. They also face difficulties wearing a bikini while swimming, since the stoma can be seen (Grant et al., 2011; Sun et al., 2013).

Table 2 Perspectives' of colorectal cancer on needs: overview of analytical, descriptive and subtheme

\begin{tabular}{|c|c|c|}
\hline Subtheme & Descriptive themes & Analytical themes \\
\hline information using appropriate media & \multirow[t]{5}{*}{ daily activities information } & \multirow[t]{8}{*}{ information needs } \\
\hline toileting information & & \\
\hline obstacles to having sex & & \\
\hline wearing comfortable clothing & & \\
\hline additional insurance needed & & \\
\hline early diet information & \multirow[t]{3}{*}{ choosing the right food } & \\
\hline paying attention while eating & & \\
\hline awareness of food reactions & & \\
\hline toileting frequently & \multirow[t]{3}{*}{ challenges of having stoma } & \multirow[t]{8}{*}{ experiences of having stoma } \\
\hline self-control of bowel movement & & \\
\hline uncontrolled flatulence & & \\
\hline challenge of diarrhea & \multirow[t]{2}{*}{ stoma complication } & \\
\hline $\begin{array}{l}\text { difficulty dealing with constipation } \\
\text { painful ostomy wound } \\
\text { stoma side effects } \\
\text { risk of leakage }\end{array}$ & & \\
\hline feeling hopeless about illness & \multirow[t]{3}{*}{ coping process } & \\
\hline feeling discouraged & & \\
\hline $\begin{array}{l}\text { having stoma is annoying and embarrassing } \\
\text { acceptance and planning for future }\end{array}$ & & \\
\hline $\begin{array}{l}\text { enhancing colorectal cancer and stoma risk reduction } \\
\text { learning attributes of the stoma } \\
\text { return to or leaving work }\end{array}$ & keep moving forwards & \multirow[t]{4}{*}{ survival for a better life } \\
\hline $\begin{array}{l}\text { familial and spousal support } \\
\text { support by healthcare providers } \\
\text { discussion with ostomy groups }\end{array}$ & \multirow[t]{2}{*}{ support network } & \\
\hline lack of support from healthcare provider & & \\
\hline $\begin{array}{l}\text { having somebody as a good listener } \\
\text { healthcare provider always has time } \\
\text { having trust in the treatment }\end{array}$ & time for discussion & \\
\hline
\end{tabular}




\section{Choosing the right food}

In the early stages, dietary information from a dietician and information in various easy to understand formats, such as leaflets, might have a positive impact (Broughton, Bailey, Linney, 2004; Beaver et al., 2010; Appleton et al., 2013). Survivors need goals to help them to achieve a normal life, with adherence to diet and regular exercise (Anderson, Steele, Coyle, 2013). The first step is controlling the size of diet, eating small amounts frequently, and choosing a healthy diet (Anderson, Steele, Coyle, 2013; Appleton et al., 2013; Palmer et al., 2013; Brown, Greenfield, Thompson, 2016). Not all kinds of food can be consumed by CRC survivors. They need to pay more attention to what they eat (Grant et al., 2011; Palmer et al., 2013; Sun, et al., 2013), otherwise, their diet will fail (Taylor, Richardson, Cowley, 2011). Nevertheless, some patients do not adhere to their dietary instructions. They test foods to see what will happen. In other words, they experiment (Beaver et al., 2010; Landers, McCarthy, Savage, 2012), since they do not fully believe the information they are given on diet (Anderson, Steele, Coyle, 2013). Over the years, the survivors gain more knowledge of diet, especially of restricted foods such as corn, spicy foods, sugary foods, and raw vegetables (Andersson, Engström, Söderberg, 2010; Sun et al., 2014). If they choose inappropriate foods, the results are unpredictable and can lead to increased gas and cause unpleasant odours (Grant et al., 2011; Landers, McCarthy, Savage, 2012).

\section{Experiences of having a stoma}

\section{Challenge of having a stoma}

Toileting is one of the major difficulties experienced by CRC survivors with an ostomy, due to lack of control over defecation. Constantly going to the toilet is a nuisance and an embarrassment. Patients sometimes feel unsatisfied after toileting, and sleep patterns can be affected (Landers, McCarthy, Savage, 2012) as unpleasant odours from the stoma repeatedly wake them at night (Sun et al., 2013). There are several ways to control this situation, such as avoiding breakfast, scheduled toileting (Landers, McCarthy, Savage, 2012), and eating and chewing slowly to regulate bowel movements (Grant et al., 2011; Sun et al., 2013). In addition, CRC patients who sleep in a supine position minimize stoma bag dispatch. Preparation before sleeping is essential to avoid or minimize the risk of leakage (Andersson, Engström, Söderberg, 2010).

\section{Stoma complication}

Diarrhea may occur about once a fortnight as an allergic reaction to some foods (Beaver et al., 2010).
Consequently, CRC survivors need to learn how to minimize such reactions, for instance, by avoiding sweet foods and using medication (Landers, McCarthy, Savage, 2012). The weight of CRC survivors with stoma will decrease slightly since many vitamins are lost from the body through defecation and disruptions in absorption and distribution by the body. Clear understanding of diet and food information can help them retain their normal weight (Hall et al., 2012; Anderson, Steele, Coyle, 2013; Palmer et al., 2013). On the other hand, constipation is another of the adverse effects that commonly occur when CRC survivors lack information about diet. When it happens, they can experience inconvenience or pain when toileting. Dietary fiber can help to manage and control bowel movements (Landers, McCarthy, Savage, 2012), as can limiting consumption of fizzy drinks. Medication can help minimize symptoms of uncontrolled flatulence. Another common problem with having a stoma is the unpleasant odour that escapes from the ostomy (Grant et al., 2011; Sun et al., 2013), which can, however, be controlled with bowel irrigation (Broughton, Bailey, Linney, 2004; Landers, McCarthy, Savage, 2012; Brown, Greenfield, Thompson, 2016).

Having a stoma can be uncomfortable and painful (Taylor, Richardson, Cowley, 2010). Pain and symptoms should be minimized to the point where they are close to "normal" (Landers, McCarthy, Savage, 2012). CRC survivors also worry that the wound will burst open (Taylor, Richardson, Cowley, 2010; Sjövall et al., 2011). A hernia and prolapse are significant complications of stoma (Sun et al., 2013). To prevent further complications, CRC survivors must avoid heavy lifting (Grant et al., 2011), be vigilant for every emerging symptom, and follow risk reduction strategies.

\section{Coping process}

Most people are shocked when diagnosed with CRC (Broughton, Bailey, Linney, 2004). At first, patients with CRC are frightened to look at the stoma (McMullen et al., 2011; Danielsen et al., 2013). They feel embarrassed about having a stoma, which leads to a loss of self-confidence (Grant et al., 2011; Palmer et al., 2013). Male CRC survivors are often mocked and bullied by girls (Beaver et al., 2010). Rejection has a negative impact on their psychological condition and situation (van Mossel et al., 2014). Often, they are in a state of disbelief and are anxious about the future (Sahay, Gray, Fitch, 2000). Therefore, they avoid talking about cancer as a way to ease their minds. Since some find talking about their illness embarrassing, they hide the fact that they are CRC survivors, while those who are especially sensitive 
about having the illness might be provoked by the subject, and can become aggressive and angry about it (Grant et al., 2011). For others, cancer is not a taboo topic (Appleton et al., 2013).

Being a CRC survivor means living with the condition and receiving long-term care from treatment until completion (Sun et al., 2013). People with CRC suffer when they have a stoma. It also changes the lives and perspectives of their spouses and family (Sjövall et al., 2011). Hence, support is needed to change their lives and attitudes (Hall et al., 2012). Trying to accept their condition can help CRC patients to adapt successfully. They do not have any expectations before the results of diagnostic testing (Broughton, Bailey, Linney, 2004). Later, they face the choice of suffering from the illness or dealing with it positively (Sahay, Gray, Fitch, 2000). Over time, most CRC survivors try to accept their illness without complaint (Grant et al., 2011).

Each CRC survivor may have a different response to their illness. Some may become depressed that their life has changed (Landers, McCarthy, Savage, 2012) . They may despair of getting through each day when life is so hard and they have no interest in it (Hall et al., 2012; Landers, McCarthy, Savage, 2012). Unable to do anything, they feel that they are of no use to others. This results in an inability to cope with their situation (Taylor, 2001; Sjövall et al., 2011; Hall et al., 2012). Death can occur suddenly and the condition will get worse over time. Patients with CRC fear dying when in the middle of life (Sjövall et al., 2011). However, if they survive they must also face the fact that their condition will not return to normal, and they must worry about their future (Sahay, Gray, Fitch, 2000; Taylor, 2001).

\section{Surviving for a better life}

\section{Keep moving forwards}

To accept their illness, CRC patients must have a good knowledge and understanding of the illness (Beaver et al., 2010; Danielsen et al., 2013). They must have a positive mindset about the illness, which can strengthen their coping mechanism for dealing with it. Additionally, learning to live with the illness and trying to lead a normal life can help them get through the situation (Grant et al., 2011). Enjoying life by doing all former activities as before can help them get through it (Sjövall et al., 2011; Palmer et al., 2013). They should foster an attitude of "counting their blessings" since other people might be even worse off than themselves (Sahay, Gray, Fitch, 2000; McMullen et al., 2011).

CRC survivors need to recognize the signs of a healthy stoma. The stoma should be reddish around the outside and the peristomal skin area should be clean (McMullen et al., 2011). It is essential to be prepared for a leakage, since leakages can occur at any time (Hall et al., 2012). In order to keep the stoma in good condition, CRC survivors need to know how to change the ostomy bag independently. Firstly they are shown how to do it, and then they are given the chance to practice handling it (Danielsen et al., 2013; Sun et al., 2014). An ostomy pouch is essential for collecting faeces. Families and friends should also be informed about the kind of ostomy pouches that are most effective and efficient to use (Sun et al., 2014).

Redefining the future is another way to accept the illness (Sun et al., 2013). CRC survivors should think positively about returning to a normal life and doing daily activities as usual (Anderson, Steele, Coyle, 2013). Patients with CRC need to organize their lives very well (Appleton et al., 2013). The cancer can act as a reminder to them (Landers, McCarthy, Savage, 2012) that anything can happen at any time in life. (Hall et al., 2012). As a result, CRC patients may appreciate life much more (Taylor, Richardson, Cowley, 2010). They are obliged to change their lifestyle and behavior to stay healthy (Palmer et al., 2013). All in all, by trying to become a different person they can actually create a better life for themselves (Anderson, Steele, Coyle, 2013). Returning to work or leaving are dilemmas for CRC survivors. A number of patients look forward to returning to work, and plan to work fulltime (Andersson, Engström, Söderberg, 2010; Landers, McCarthy, Savage, 2012). While they may want to return to work, they will need to convince their workplace that they are able to do so (Broughton, Bailey, Linney, 2004). On the other hand, some survivors chose to give up working, since work no longer has meaning in their life (Appleton et al., 2013).

\section{Support network}

Information about cancer charity networks is also needed by ostomates (Appleton et al., 2013). One reason is that the cost of treatment is expensive, and covered by out-of-pocket financing. With the high cost of treatment and lack of financial support, it is beneficial if patients have insurance to cover the cost.

Life partners/spouses are one of the most important sources of support for CRC survivors. Therefore they need to be involved in the healthcare process (Sjövall et al., 2011). Having the support of a partner can help CRC survivors to adapt to their situation (Grant et al., 2011). When the condition of patients worsens, it is beneficial to mobilize all family members in raising their spirits (Grant et al., 2011; Sjövall et al., 2011; Hall et al., 2012). Relatives and those close to survivors can provide them with positive energy 
(Sjövall et al., 2011). Their encouragement helps CRC survivors to learn to live with cancer (Sun et al., 2013), and they provide the various kinds of support needed by the patients (Hall et al., 2012). However, families in particular are anxious and frightened of the illness. They must know all about stoma to have a better understanding of the illness (Danielsen et al., 2013). Groups of other survivors give crucial support to CRC survivors with an ostomy. Being part of an ostomy group is empowering and has a positive impact on new CRC survivors (Anderson, Steele, Coyle, 2013; Sun et al., 2014). They can share experiences with other CRC survivors who have learned to enjoy life after having a stoma, and thus increase their understanding of how to survive through the illness and their enthusiasm to do so (Sun et al., 2013).

\section{Time for discussion}

Feeling miserable and depressed is a normal reaction to having a stoma. In order to minimize negative reactions, CRC survivors need to talk with someone who can ease their stress (Grant et al., 2011; Sjövall et al., 2011), since family often do not understand what they are going through. Humor is one of many ways to reduce the stress and suffering of survivors (Sun et al., 2013). In addition, having a good listener who survivors can talk to and share experiences with is important (Grant et al., 2011; Sjövall et al., 2011; Hall et al., 2012). Family members who act as healthcare providers can play an essential role in providing information and discussing health developments (Andersson, Engström, Söderberg, 2010).

Healthcare providers make maximum efforts to treat the illness or reduce the emerging symptoms. They directly control and manage interventions and are involved in taking care of CRC survivors (Sjövall et al., 2011). Healthcare providers should be kind and supportive, giving positive advice and visiting patients to check up on their current physical symptoms (Sun et al., 2014). They also make home visits once a week, inquiring about CRC survivors' health conditions and the development of their illness (Hall et al., 2012). Healthcare providers immerse themselves in the lives of patients and family, providing information clearly, in simple terms (Broughton, Bailey, Linney, 2004; Beaver et al., 2010). When information is shared with the family and patients, it gives them the opportunity to ask about anything related to the illness (Sun et al., 2013). Healthcare providers are good listeners who provide information in a comprehensible way to CRC survivors and family (Broughton, Bailey, Linney, 2004). They also play a crucial spiritual role for CRC survivors with ostomies (Hall et al., 2012; Sun et al., 2014). As a result, CRC survivors feel grateful for the services provided (Sun et al., 2013). However, in some areas, healthcare providers have limited time in which to talk to and support CRC survivors (Sahay, Gray, Fitch, 2000; Hall et al., 2012).

\section{Discussion}

The results of this study summarize the literature on the needs of adult survivors of CRC with ostomies. The themes of the synthesis relate to the needs of adult CRC survivors: information needs (daily information, choosing the right food), experiences of having stoma (challenge of having stoma, stoma complication, coping process) and surviving towards a better life (keep moving forwards, support networks, sharing experiences with other survivors). On the other hand, the study also found several issues that are commonly raised by survivors, such as difficulties in finding a suitable stoma bag for everyday use and for travelling. Sex was another issue for survivors. Understanding CRC survivors' needs can help us to provide precisely the support they require to continue their daily activities.

CRC survivors are faced with adapting to various changes in their daily life due to the illness (Kimura, Kamada, Guilhem, 2016), and they need accurate information to deal with it. Information is needed on how to treat stoma, the process of stoma wound healing, complications that can occur in the stoma and the skin around the stoma, as well as advice on preventative measures that can be taken, and the types of food and beverages that must be consumed or avoided by CRC survivors. This information should be provided gradually and continuously until CRC survivors fully know and understand it. When information is not conveyed properly, it can have a negative impact on their condition. In addition, information regarding daily activities can help them accept their condition and prepare ways to overcome the difficult situations they will face. As a trusted and recommended source of information, healthcare workers need to share information clearly and understandably, taking into account several issues such as culture, language, and others (van Mossel et al., 2014). Using social media to share information may give survivors more opportunity to communicate, increase understanding of their conditions (Pellino et al., 2017), and enhancing their health literacy (Aoki, Inoue, 2017). On the other hand, information from social media often lacks validation (Sajid, Shakir, Baig, 2011).

Trauma and stress commonly occur in survivors' first year as cancer survivors (Graça Pereira, Figueiredo, Fincham, 2012). Stress can be triggered by financial problems, lack of knowledge, limited information, lack of support (Wang et al., 2016), recovery time, 
adverse effects of treatment, and anxiety about how they can continue their lives (Hoekstra, Heins, Korevaar, 2014). In addition, stoma creation can make it difficult for CRC survivors to adapt to their new lives, and as a result, they need information from professional healthcare workers about ostomies (Danielsen et al., 2013). The majority of survivors do not take care of their own stoma even though training is given in hospital (Kelly et al., 2016). During their first year as survivors, patients commonly complain of stoma complications and suffer from conditions that affect their psychological health. In addition, CRC survivors with ostomies face a range of difficulties: sexual and psychological problems, issues related to clothing, complications when going on vacation, and others (Vonk-Klaassen et al., 2016). Sexual difficulties are common among CRC survivors, particularly among ostomy patients (Donovan, Thompson, Hoffe, 2010; Reese et al., 2014). The severity of sexual problems depends on the current condition and treatment procedures of the survivors (Averyt, Nishimoto, 2014), which are linked to demographic, medical and psychosocial factors (Milbury et al., 2013). Assessing sexual dysfunction, and providing information, support and treatment options can help survivors to function sexually (Traa et al., 2012). However, only a few survivors willingly answer and discuss sexual dysfunction (Averyt, Nishimoto, 2014), due to feelings of shame (Oskay, Can, Basgol, 2014). Another crucial need of CRC survivors is to choose the most appropriate food, and they must focus carefully on dietary information (Beeken et al., 2016). Some foods produce unpredictable reactions, and survivors need to pay attention to what they consume and be aware of the effects of various foods.

Returning to work is also a challenge for survivors. It is affected by several factors such as environment, personality, work demands, ability to work, health status, and financial status of survivors and family (Chow, Ting, Su, 2014). A third of survivors stop working within a year of surgery (Bhalla et al., 2014). Empowering survivors to accept and live their lives is crucial to improving their quality of life, achieving a fast recovery, and returning to work. A positive mind-set and support from relatives, friends, the community, and healthcare providers will increase understanding and acceptance in CRC survivors. Provision of adequate information on how to survive CRC, and family support have a huge impact on the chances of CRC survivors successfully recovering from cancer and setting goals for the future. In addition, CRC survivors need friends and someone to exchange thoughts and opinions with in order to have quality of life.

\section{Limitation of study}

Despite some limitations, we have described the needs of CRC survivors. We used a large number of search terms to discover as many as possible. However, it is possible the authors missed further relevant articles relating to the terms. The review focused on published journals rather than other possible sources, such as grey literature, and the primary research for this study used only English publications, meaning the results of the study are not necessarily appropriate to nonEnglish speaking countries. In further research, combining the qualitative study could give strong descriptions, explanations, and interpretations from diverse settings rather than an individual primary study. Future work should be undertaken to investigate needs based on length of time as CRC survivors, e.g., $<1$ year, 1-3 years, and long-term survivors, and the needs of both survivors of productive age and old age, relating to their situations and cultural practices associated with the illness.

\section{Conclusion}

The study indicated that there is important information that should be conveyed to CRC survivors such as advice on toileting, sex, wearing comfortable clothing, and how to choose the diet most appropriate for them. Moreover, they require information regarding the stoma and peristomal complications (e.g., the challenges of having a stoma, control of flatulence and constipation, and how to minimize the risk of stoma and peristomal complications). Despite their need of support, CRC survivors with ostomies also complain that they feel uncared for/neglected by their family, friends, and health professionals. Hence, support and communication from spouses, family, and health workers as a support system will increase their acceptance of their illness and health condition, and having the opportunity to relate their experiences to a sympathetic listener can improve the quality of life of CRC survivors.

\section{Ethical aspects and conflict of interest}

The authors declare no conflicts of interest for the research, authorship and publication of this article.

\section{Acknowledgements}

Authors wish to thank Kementerian Riset, Teknologi dan Pendidikan Tinggi of Indonesia (Ministry of Research, Technology and Higher Education of Indonesia) and STIKes Muhammadiyah Palembang, South Sumatera for the scholarship. 


\section{Author contributions}

Conception and design (YT, PS, BS), data analysis and interpretation (YT, PS, BS, CS), manuscript draft (YT), critical revision of the manuscript (YT, PS, BS, $\mathrm{CS}$ ), final approval of the manuscript (YT).

\section{References}

Anderson AS, Steele R, Coyle J. Lifestyle issues for colorectal cancer survivors - perceived needs, beliefs and opportunities. Supportive Care in Cancer. 2013;21(1):35-42.

Andersson G, Engström Å, Söderberg S. A chance to live: women's experiences of living with a colostomy after rectal cancer surgery. International Journal of Nursing Practice. 2010;16(6):603-608.

Aoki T, Inoue M. Association between health literacy and patient experience of primary care attributes: a cross-sectional study in Japan. PLoS One. 2017;12(9):e0184565.

Appleton L, Goodlad S, Irvine F, Poole H, Wall C. Patients' experiences of living beyond colorectal cancer: a qualitative study. European Journal of Oncology Nursing. 2013;17(5):610-617.

Arnold M, Sierra MS, Laversanne M, Soerjomataram I, Jemal A, Bray F. Global patterns and trends in colorectal cancer incidence and mortality. Gut. 2017;66(4):683-691.

Averyt JC, Nishimoto PW. Addressing sexual dysfunction in colorectal cancer survivorship care. Journal of Gastrointestinal Oncology. 2014;5(5):388-394.

Beaver K, Latif S, Williamson S, Procter D, Sheridan J, Heath J, Susnerwala S, Luker K. An exploratory study of the followup care needs of patients treated for colorectal cancer. Journal of Clinical Nursing. 2010;19(23-24):3291-3300.

Beeken RJ, Williams K, Wardle J, Croker H. "What about diet?" A qualitative study of cancer survivors' views on diet and cancer and their sources of information. European Journal of Cancer Care. 2016;25(5):774-783.

Bhalla A, Williams JP, Hurst NG, Speake WJ, Tierney GM, Tou S, Lund JN. One-third of patients fail to return to work 1 year after surgery for colorectal cancer. Techniques of Coloproctology. 2014;18(12):1153-1159.

Broughton M, Bailey J, Linney J. How can experiences of patients and carers influence the clinical care of large bowel cancer? European Journal of Cancer Care. 2004;13(4):318327.

Brown S, Greenfield D, Thompson J. Knowledge and awareness of long-term and late treatment consequences amongst colorectal cancer survivors: a qualitative study. European Journal of Oncology Nursing. 2016;20:191-198. Campbell R, Pound P, Morgan M, Daker-White G, Britten N, Pill R, Yardley L, Pope C, Donovan J. Evaluating metaethnography: systematic analysis and synthesis of qualitative research. Health Technology Assessment. 2011;15(43):1-164. Center MM, Jemal A, Smith RA, Ward E. Worldwide variations in colorectal cancer. CA: a Cancer Journal for Clinicians. 2009;59(6):366-378.

Chow SL, Ting AS, Su TT. Development of conceptual framework to understand factors associated with return to work among cancer survivors: a systematic review. Iranian Journal of Public Health. 2014;43(4):391-405.

Coffey L, Mooney O, Dunne S, Sharp L, Timmons A, Desmond D, O'Sullivan E, Timon C, Gooberman-Hill R, Gallagher P. Cancer survivors' perspectives on adjustmentfocused self-management interventions: a qualitative meta- synthesis. Journal of Cancer Survivorship. 2016;10(6):10121034.

Danielsen AK, Soerensen EE, Burcharth K, Rosenberg J. Learning to live with a permanent intestinal ostomy: impact on everyday life and educational needs. Journal of Wound, Ostomy, and Continence Nursing. 2013;40(4):407-412.

Denlinger CS, Barsevick AM. The challenges of colorectal cancer survivorship. Journal of the National Comprehensive Cancer Network. 2009;7(8):883-893.

Denlinger CS, Engstrom PF. Colorectal cancer survivorship: movement matters. Cancer Prevention Research. 2011;4(4):502-511.

Donovan KA, Thompson LM, Hoffe SE. Sexual function in colorectal cancer survivors. Cancer Control. 2010;17(1):4451.

Edwards J, Kaimal G. Using meta-synthesis to support application of qualitative methods findings in practice: a discussion of meta-ethnography, narrative synthesis, and critical interpretive synthesis. The Arts in Psychotherapy. 2016;51:30-35.

Favoriti P, Carbone G, Greco M, Pirozzi F, Pirozzi RE, Corcione F. Worldwide burden of colorectal cancer: a review. Updates in Surgery. 2016;68(1):7-11.

Ferlay J, Steliarova-Foucher E, Lortet-Tieulent J, Rosso S, Coebergh JW, Comber H, Forman D, Bray E. Cancer incidence and mortality patterns in Europe: estimates for 40 countries in 2012. European Journal of Cancer. 2013;49(6):1374-1403.

Graça Pereira M, Figueiredo AP, Fincham FD. Anxiety, depression, traumatic stress and quality of life in colorectal cancer after different treatments: a study with Portuguese patients and their partners. European Journal of Oncology Nursing. 2012;16(3):227-232.

Grant M, McMullen CK, Altschuler A, Mohler MJ, Hornbrook MC, Herrinton LJ, Wendel CS, Baldwin CM, Krouse RS Gender differences in quality of life among long-term colorectal cancer survivors with ostomies. Oncology Nursing Forum. 2011;38(5):587-596.

Haggar FA, Boushey RP. Colorectal cancer epidemiology: Incidence, mortality, survival, and risk factors. Clinics in Colon and Rectal Surgery. 2009;22(4):191-197.

Hall S, Gray N, Browne S, Ziebland S, Campbell NC. A qualitative exploration of the role of primary care in supporting colorectal cancer patients. Supportive Care in Cancer. 2012;20(12):3071-3078.

Hoekstra RA, Heins MJ, Korevaar JC. Health care needs of cancer survivors in general practice: a systematic review. BMC Family Practice. 2014;15:94.

Kelly KN, Noyes K, Dolan J, Fleming F, Monson JR, Gonzalez M, Sevdalis N, Dozier A. Patient perspective on care transitions after colorectal surgery. Journal of Surgical Research. 2016;203(1):103-112.

Kimura CA, Kamada I, Costa de Jesus CA, Guilhem D. Quality of life of colorectal cancer patients with intestinal stomas. Journal of Carcinogenesis and Mutagenesis. 2014;S10:007.

Kimura CA, Kamada I, Guilhem DB, Ribeiro Modesto K, Silva de Abreu B. Perceptions of ostomized persons due to colorectal cancer on their quality of life. Journal of Coloproctology. 2016;33(4):236-221.

Kimura CA, Kamada I, Guilhem D. Quality of life of stomized oncological people: an approach of integrality from Brazilian Unified Health System. Journal of Coloproctology. 2016;36(1):34-39.

Landers M, McCarthy G, Savage E. Bowel symptom experiences and management following sphincter saving 
surgery for rectal cancer: a qualitative perspective. European Journal of Oncology Nursing. 2012;16(3):293-300.

Mahjoubi B, Mirzaei R, Azizi R, Jafarinia M, Zahedi-Shoolami L. A cross-sectional survey of quality of life in colostomates: a report from Iran. Health and Quality of Life Outcomes. 2012;10:136.

McMullen CK, Wasserman J, Altschuler A, Grant ML, Hornbrook MC, Liljestrand P, Briggs C, Krouse RS. Untreated peristomal skin complications among long-term colorectal cancer survivors with ostomies. Clinical Journal of Oncology Nursing. 2011;15(6):644-650.

Milbury K, Cohen L, Jenkins R, Skibber JM, Schover LR. The association between psychosocial and medical factors with long-term sexual dysfunction after treatment for colorectal cancer. Supportive Care in Cancer. 2013;21(3):793-802.

Moher D, Liberati A, Tetzlaff J, Altman DG; PRISMA Group. Preferred reporting items for systematic reviews and metaanalysis: the PRISMA Statement. PLoS Medicine. 2009;6(7):e1000097.

Oskay U, Can G, Basgol S. Discussing sexuality with cancer patients: oncology nurses attitudes and views. Asian Pacific Journal of Cancer Prevention. 2014;15(17):7321-7326.

Palmer NR, Bartholomew LK, McCurdy SA, Basen-Engquist $\mathrm{KM}$, Naik AD. Transitioning from active treatment: colorectal cancer survivors' health promotion goals. Palliative and Supportive Care. 2013;11(2):101-109.

Pellino G, Simillis C, Qiu S, Rasheed S, Mills S, Warren O, Kontovounisios C, Tekkis PP. Social media and colorectal cancer: a systematic review of available resources. PLoS One. 2017;12(8):e0183031.

Reese JB, Finan PH, Haythornthwaite JA, Kadan M, Regan KR, Herman JM, Efron J, Diaz LA Jr, Azad NS. Gastrointestinal ostomies and sexual outcomes: a comparison of colorectal cancer patients by ostomy status. Supportive Care in Cancer. 2014;22(2):461-468.

Ring N, Jepson R, Ritchie K. Methods of synthesizing qualitative research studies for health technology assessment. International Journal of Technology Assessment in Health Care . 2011;27(4):384-390.

Sahay TB, Gray RE, Fitch M. A qualitative study of patient perspectives on colorectal cancer. Cancer Practice. 2000;8(1):38-44.

Sajid MS, Shakir AI, Baig MK. Information on the internet about colorectal cancer: patient attitude and potential toward web browsing. A prospective observational study. Canadian Journal of Surgery. 2011;54(5):339-343.

Salz T, Baxi SS, Blinder VS, Elkin EB, Kemeny MM, McCabe MS, Moskowitz CS, Onstad EE, Saltz LB, Temple LK, Oeffinger KC. Colorectal cancer survivors' needs and preferences for survivorship information. Journal of Oncology Practice / American Society of Clinical Oncology. 2014;10(4):e277-e282.

Siegel RL, Miller KD, Jemal A. Cancer statistics, 2015. CA: A Cancer Journal for Clinicians. 2015;65(1):5-29.

Sjövall K, Gunnars B, Olsson H, Thomé B. Experiences of living with advanced colorectal cancer from two perspectives - inside and outside. European Journal of Oncology Nursing. 2011;15(5):390-397.

Stewart BW, Wild CP, editors. World cancer report 2014. Lyon: World Health Organization; 2014.

Sun V, Grant M, McMullen CK, Altschuler A, Mohler MJ, Hornbrook MC, Herrinton LJ, Baldwin CM, Krouse RS. Surviving colorectal cancer: long-term, persistent ostomyspecific concerns and adaptations. Journal of Wound, Ostomy and Continence Nursing. 2013;40(1):61-72.

Sun V, Grant M, McMullen CK, Altschuler A, Mohler MJ, Hornbrook MC, Herrinton LJ, Krouse RS. From diagnosis through survivorship: health-care experiences of colorectal cancer survivors with ostomies. Supportive Care in Cancer. 2014;22(6):1563-1570.

Sung JJ, Lau JY, Goh KL, Leung WK; Asia Pacific Working Group on Colorectal Cancer.. Increasing incidence of colorectal cancer in Asia: Implications for screening. The Lancet. Oncology. 2005;6(11):871-876.

Taylor C. Patients' experiences of 'feeling on their own' following a diagnosis of colorectal cancer: a phenomenological approach. International Journal of Nursing Studies. 2001;38(6):651-661.

Taylor C, Richardson A, Cowley S. Restoring embodied control following surgical treatment for colorectal cancer: a longitudinal qualitative study. International Journal of Nursing Studies. 2010;47(8):946-956.

Taylor C, Richardson A, Cowley S. Surviving cancer treatment: an investigation of the experience of fear about, and monitoring for, recurrence in patients following treatment for colorectal cancer. European Journal of Oncology Nursing. 2011;15(3):243-249.

Thomas J, Harden A. Methods for the thematic synthesis of qualitative research in systematic reviews. BMC Medical Research Methodology. 2008;8:45.

Torre LA, Bray F, Siegel RL, Ferlay J, Lortet-Tieulent J, Jemal A. Global cancer statistics, 2012. CA: A Cancer Journal for Clinicians. 2015;65(2):87-108.

Traa MJ, De Vries J, Roukema JA, Den Oudsten BL. Sexual (dys)function and the quality of sexual life in patients with colorectal cancer: a systematic review. Annals of Oncology. 2012;23(1):19-27.

van Mossel C, Leitz L, Watson H, Daudt H, Alford M, Mitchell A, Coady N, Payeur N. Learning from the collective story: Information needs of people with colorectal cancer. Journal of Nursing Education and Practice. 2014;4(8):125-139.

Vonk-Klaassen SM, de Vocht HM, den Ouden MEM, Eddes EH, Schuurmans MJ. Ostomy-related problems and their impact on quality of life of colorectal cancer ostomates: a systematic review. Quality of Life Research. 2016;25:125-133. Wang JW, Shen Q, Ding N, Zhang TR, Yang ZQ, Liu C, Chen SJ, Berry HL, Yuan ZP, Yu JM. A qualitative exploration of the unmet psychosocial rehabilitation needs of cancer survivors in China. Psycho-Oncology. 2016;25(8):905-912. 